\title{
Evaluation of some oral postradiotherapy sequelae in patients treated for head and neck tumors
}

\author{
Avaliação de algumas seqüelas bucais \\ pós-radioterapia em pacientes tratados de \\ neoplasias de cabeça e pescoço
}

\begin{abstract}
Cássia Maria Fischer Rubira ${ }^{(a)}$
Nádia Juliana Devides ${ }^{(b)}$

Liliane Torsani Úbeda ${ }^{(b)}$

Antônio Geraldo Bortolucci Jr(c) José Roberto Lauris ${ }^{(d)}$

Izabel Regina Fischer Rubira-Bullen ${ }^{(\mathrm{d})}$

José Humberto Damante ${ }^{(e)}$
\end{abstract}

(a) PhD Student; (b) Undergraduate Students; (d) Associate Professors; ${ }^{(e)}$ Professor and Chairman - Stomatology Department, School of Dentistry of Bauru, University of Sao Paulo.

(c)DDS, Bucomaxillofacial surgeon, Amaral Carvalho Hospital, Jaú, SP, Brazil.

\begin{abstract}
The aim of this study was to evaluate the oral sequelae of radiotherapy in patients treated between 1999 and 2003 for head and neck tumors. One-hundred patients ( 24 women, 76 men) ranging in age from 30 to 83 years (mean 59.2 years) were examined. Time since radiotherapy ranged from 1 to 72 months (mean 28 months). The total mean radiation dose received by the patients was $5,955 \mathrm{cGy}$. The evaluation protocol included anamnesis, intraoral and extraoral examination, measurement of stimulated salivary flow and salivary $\mathrm{pH}$. Symptoms reported by the patients included dry mouth $(68 \%)$, dysphagia $(38 \%)$, and dysgeusia $(30 \%)$. In $64 \%$ of the patients, the mean stimulated salivary flow rate was less than $0.7 \mathrm{ml} / \mathrm{min}$. The mean salivary $\mathrm{pH}$ was $6.97( \pm 0.714)$. Stimulated salivary flow increased with increasing postradiotherapy time $(\mathrm{p}<0.05)$. The prevalence of mucositis was associated with higher radiation doses $(\mathrm{p}<0.05)$, and the prevalence of atrophic candidiasis was related to a longer post-treatment period $(\mathrm{p}<0.05)$. Two cases of recurrence of the primary tumor were detected during the study. The main effect of radiotheraphy in the head and neck region was a reduction of the salivary flow rate, even though our study demonstrated that there was a modest late improvement of the salivary flow.
\end{abstract}

Descriptors: Radiotherapy; Xerostomia; Saliva; Head and neck neoplasms.

Resumo: O objetivo deste estudo foi avaliar as seqüelas bucais provocadas pela radioterapia em pacientes com neoplasias de cabeça e pescoço, tratados entre 1999 e 2003. Foram examinados 100 pacientes ( 24 mulheres e 76 homens), com idades entre 30 e 83 anos (média de 59,2 anos). O tempo desde a radioterapia variou de 1 a 72 meses (média de 28 meses). A média da dose total de radiação recebida pelos pacientes foi de 5.955 cGy. O protocolo de avaliação consistiu de anamnese, exame físico, aferição do fluxo salivar estimulado e pHmetria da saliva. Os sintomas referidos foram boca seca (68\%), disfagia $(38 \%)$ e disgeusia (30\%). Em 64\% dos indivíduos o valor médio do fluxo salivar estimulado esteve abaixo de $0.7 \mathrm{ml} / \mathrm{min}$. O pH médio da amostra foi de 6.97 ( \pm 0.714 ). O fluxo estimulado e a ocorrência de candidíase atrófica aumentaram conforme o aumento do tempo pós-radioterapia $(\mathrm{p}<0.05)$. A ocorrência de mucosite esteve associada a maiores doses de radiação $(\mathrm{p}<0.05)$. Dois casos de segundo tumor primário foram diagnosticados. $\mathrm{O}$ principal efeito da radioterapia na região de cabeça e pescoço foi a redução do fluxo salivar, apesar de nosso estudo ter demonstrado que há uma melhora tardia do fluxo salivar. Descritores: Radioterapia; Xerostomia; Saliva; Neoplasias de cabeça e pescoço. 


\section{Introduction}

The expression "head and neck tumors" comprises a large number of tumors with different histological characteristics arising from various anatomical sites such as the lip semimucosa, oral mucosa, pharynx, larynx, cervical portion of the esophagus, paranasal sinuses, salivary glands, thyroid, parathyroid, and skin. ${ }^{11}$

Surgery, radiotherapy and chemotherapy applied alone or in combination are used for cancer treatment. Radiotherapy is aimed at eliminating or reducing the number of neoplastic cells without exceeding the tolerance of normal tissues, one of the most important factors for limiting the dose. The duration of radiotherapy, the field to be irradiated and the radiation dose are factors that determine the extent and intensity of local sequelae. Immediate (acute) complications observed at the beginning and during radiotherapy are mucositis, xerostomia, dysgeusia, dysphagia, candidiasis and others. ${ }^{3}$ Late occurrences such as osteoradionecrosis may be expected.

The objective of the present study was to evaluate the postradiotherapy oral health status in patients treated for head and neck tumors at the Amaral Carvalho Hospital, Jaú, SP, Brazil.

\section{Material and Methods}

A total of 1,104 records from patients treated for head and neck tumors at the Radiotherapy Service, Amaral Carvalho Hospital, Jaú, SP, Brazil, between 1999 and 2003, were analyzed. Only 115 patients accepted the invitation and 100 completed the evaluation process. All patients received detailed information about the study and signed an informed consent form. The study was approved by the Ethics Committee of the institution.

The patients were submitted to thorough clinical examination consisting of anamnesis and physical exams aimed at the detection of radiotherapy sequelae. Complementary exams included sialometry, measurement of salivary $\mathrm{pH}$ and panoramic radiography.

Data regarding the primary tumor, types of treatment, radiation field, and total radiation dose were collected from the hospital records. The patients were classified according to the use or not of medications causing xerostomia (hypotensive, anxiolytic, antidepressive, diuretic, antidiabetic, anorexic, antiinflammatory, and antiparkinson drugs). ${ }^{12}$

For stimulated sialometry, the patients chewed a piece of surgical latex tube $(1.0 \times 0.5 \mathrm{~cm}$, Auriflex, São Roque, SP, Brazil) attached to dental floss for 5 min, and saliva was collected into a transparent millimeter-graded container. ${ }^{18}$ Two saliva samples were obtained at an interval of $15 \mathrm{~min}$. Patients presenting a mean of both stimulated saliva flow rates less than $0.7 \mathrm{ml} / \mathrm{min}$ were classified as xerostomic. ${ }^{7}$ The patients were instructed not to eat anything at least one hour before the exam.

Salivary pH was measured by a portable apparatus (Sentron, model 1001, Roden, Drenthe, Holland) calibrated at the beginning of each day with two standard solutions ( $\mathrm{pH} 7.0$ and 4.0). The measurements were made immediately after sialometry. The mean value of the two $\mathrm{pH}$ measurements was obtained, which corresponded to the $\mathrm{pH}$ of each subject. ${ }^{18}$

\section{Results}

The 100 patients studied were divided in 24 women and 76 men, with a proportion of approximately 1:3. The mean age of the sample was 59.2 years (30-83 yrs).

Most of the patients (9 women, 58 men) had squamous cell carcinoma (SCC); basocellular carcinoma accounted for $8 \%$ of the neoplasms, and other tumors accounted for $25 \%$. The most frequent site of tumors was the mouth $(30 \%)$, distributed at the tongue $(14 \%)$, gingiva $(7 \%)$, mouth floor $(5 \%)$ and lips (4\%). The other sites were pharynx $(20 \%)$, larynx $(14 \%)$, salivary glands $(5 \%)$, thyroid $(5 \%)$, nasal cavity and paranasal sinus (3\%), and other sites (23\%).

The sample distribution, according to total radiation dose received, was $68 \%$ between 5,000 and 7,000 cGy and 20\% between 7,001 and 8,000 cGy, meaning that $89 \%$ were treated with doses higher than 5,000 cGy. The mean total dose received by the patients was 5,955 cGy.

The mean postradiotherapy time, one of the parameters analyzed to evaluate the sequelae of radio- 
therapy, was 28 months (1-72 months). Thirty nine percent had up to 12 months of postradiotherapy time, $15 \%$ up to $24,12 \%$ up to $36,15 \%$ up to 48 and $19 \%$ up to or more than 60 months.

Symptoms corresponding to possible sequelae of radiotherapy reported by the patients upon anamnesis were dysgeusia in 30\%, dysphagia in $38 \%$, and xerostomia in $68 \%$. Forty-three percent of the patients were completely edentulous. There were no complaints of trismus nor was it clinically detected.

No clinical or radiographic signs of osteoradionecrosis were observed. High risk for caries and periodontal disease was detected in just one patient.

Two male patients (50 and 61 years) treated for SCC had indication for intraoral biopsy. In the first case, the time since radiotherapy $(6,300 \mathrm{cGy})$ was 23 months and the lesion was an erythematous asymptomatic macula located next to the surgical scar. In the second case, the time since radiotherapy (5,000 cGy) was 72 months and the lesion was a red spot with whitish points located in the left retromolar region. The microscopic results were of SCC.

The $t$-Student test was used to investigate possible differences between the sequelae groups (dysgeusia, dysphasia, dry mouth, mucositis, candidiasis) and the non-sequelae groups, regarding postradiotherapy time and treatment radiation dose.

The candidiasis group showed a statistically significant higher postradiotherapy time $(39.3 \pm 19.2$ months, $\mathrm{p}=0.028$ ) than that of the group without candidiasis (25 \pm 19.6 months). A significant difference was also found between the radiation dose of the group with mucositis $(7,520 \pm 3,507 \mathrm{cGy}$; $\mathrm{p}=0.044)$ and that of the group without mucositis $(5,914 \pm 3,507 \mathrm{cGy})$. There were no significant differences between the other groups.

Stimulated salivary flow was less than $0.7 \mathrm{ml} /$ $\min$ in $64 \%$ of the patients (hyposalivation). ${ }^{9}$ After five minutes, sufficient saliva could not be collected for sialometry from 15 of these patients and their salivary flow was therefore considered to be zero (Graph 1).

The sample was divided into three groups according to inclusion of the salivary glands in the irradiated field. In group $1(\mathrm{n}=39)$, only the face was included in the radiation field, with most patients be- ing treated for tumors of the mouth, salivary glands and maxillary sinus. In group $2(\mathrm{n}=23)$, only the neck but not the face was included in the radiation field. Most patients were treated for thyroid or vocal cord tumors. In group 3 ( $\mathrm{n}=38$, patients with oropharyngeal cancer) the neck and face were included in the radiation field. Backward stepwise multiple regression analysis was applied to determine the combined effect of the variables radiation field, dose, use of xerostomic drugs and postradiotherapy time on salivary flow. The variables showing statistical significance $(\mathrm{p}<0.05)$ remained in the model. The results of multiple regression analysis are shown in Table 1 . The only variable that showed no significant correlation with salivary flow was the radiation dose.

Salivary $\mathrm{pH}$ was measured in 93 patients, with a total of 186 results. The system permitted $\mathrm{pH}$ measurement with a single drop of saliva. It was there-

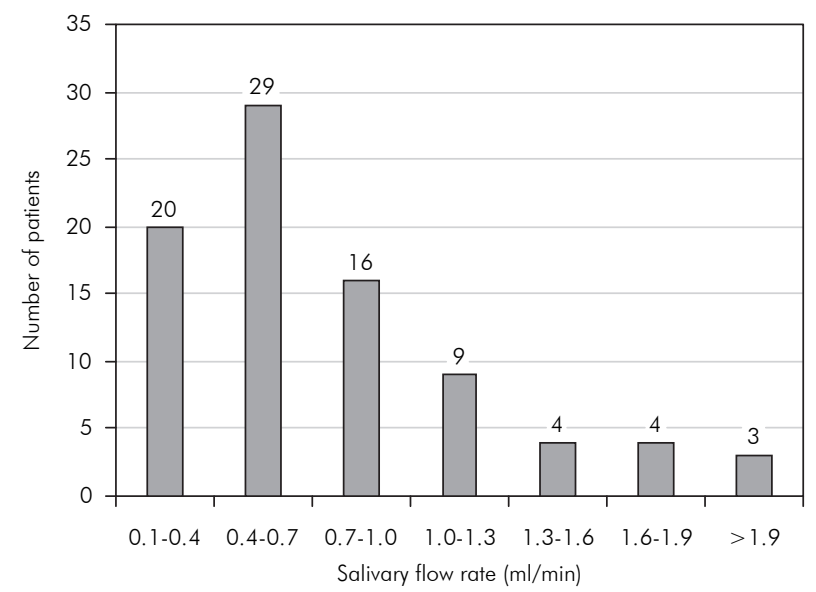

Graph 1 - Stimulated salivary flow rate in the irradiated patients.

Table 1 - Results of multiple linear regression analysis: radiation field in Group 1 and Group 3, use of xerostomic drugs and postradiotherapy time on salivary flow.

\begin{tabular}{l|c|c|c}
\hline \multicolumn{1}{c|}{ Independent Variables } & $\beta$ & $p$ & $\begin{array}{c}r^{2} \\
\text { adjusted }\end{array}$ \\
\cline { 1 - 2 } Radiation field (Face/Group 1) & -0.3377 & 0.007 & \\
\cline { 1 - 2 } Radiation field (Face/Neck/Group 3) & -0.3356 & 0.008 & \multirow{2}{*}{0.13} \\
\cline { 1 - 2 } Use of xerostomic drugs & -0.2079 & 0.037 & \\
\cline { 1 - 2 } Postradiotherapy time & 0.2307 & 0.020 & \\
\hline
\end{tabular}


fore possible to measure $\mathrm{pH}$ in 12 out of the $15 \mathrm{pa}$ tients who were unable to perform sialometry. The mean $\mathrm{pH}$ of the sample was $6.97 \pm 0.71$.

\section{Discussion}

Squamous cell carcinoma (SCC) was the most prevalent tumor in the present study (67\%). According to the literature, this tumor accounts for $90 \%$ of all malignant neoplasms of the mouth and pharynx. ${ }^{1}$ The prevalence of oral cancer in our study was higher among males $(27 \%)$ than among females $(8 \%)$, with a ratio of $3.3: 1$. The number of new cases of oral cancer for 2006 is estimated to be 10,060 among men and 3,410 among women, with a ratio of $2.9: 1,{ }^{8}$ which is similar to the ratio found in our data.

Dysgeusia is defined as an altered sense of taste resulting from reduced salivary flow and biochemical alterations in the saliva. This condition frequently occurs in irradiated patients, whose reduced salivary volume and flow impair the physical contact of foods with the taste papillae. ${ }^{9}$ These papillae are also destroyed depending on the radiation doses. ${ }^{21}$

In the present study, $30 \%$ of the patients reported total loss of taste, with these patients having received doses higher than 5,000 cGy. Post-treatment time was up to 12 months in 16 patients and ranged from 17 to 72 months in the other 14 patients. Although some of the patients were within the period of reestablishment (12 months), ${ }^{4}$ all received doses close to $6,000 \mathrm{cGy}$, implying a possibly permanent taste loss. ${ }^{13}$

Dysphagia is a difficulty in masticating and swallowing foods. ${ }^{4}$ This condition is caused by radiation fibrosis within the pharyngeal constrictor muscles. Cintra et al. ${ }^{5}$ (2005) evaluated oropharyngeal swallowing in patients treated for epidermoid carcinoma of the larynx and hypopharynx by chemotherapy in combination with radiotherapy (total dose of 7,040 cGy). Swallowing was regular in $54.8 \%$ of the sample studied (discrete to moderate dysphagia) and poor in $9.7 \%$ (severe dysphagia). In our study, 38 subjects reported swallowing difficulties (dysphagia). They received a mean radiation dose of 6,063 cGy $(4,000-10,000)$ and the radiation field included the region of the oropharynx and neck.
Xerostomia is one of the most frequent sequelae of head and neck radiotherapy because the salivary glands are radiosensitive organs. A reduction in the quality and quantity of saliva also leads to an imbalance in the microbiota and consequent occurrence of diseases. . $^{11,16,19}$

In the present study, most patients $(89 \%)$ were irradiated with a dose higher than 5,000 cGy. This protocol involves a poor prognosis regarding the return of normal glandular function. However, our results (Table 1) showed an increase in salivary secretion with increasing postradiotherapy time $(\beta=0.2307 ; p=0.020$ ). Although $89 \%$ of the sample received doses higher than 5,000 cGy and supposedly these doses cause irreversible damage to saliva production, ${ }^{10}$ no statistic correlation was observed between salivary flow and total radiation dose $(\mathrm{p}>0.05)$.

Groups 1 and 3 (Table 1), including patients whose major salivary glands were involved in the radiation field, presented a significant reduction in salivary flow $(\mathrm{p}=0.007$ and $\mathrm{p}=0.008$, respectively). Moreover, the patients using xerostomic medications (Table 1) showed a significant influence of this factor on the reduction of salivary flow $(\mathrm{p}=0.037)$.

Möller et al. ${ }^{14}$ (2004) observed a decrease in $\mathrm{pH}$ during irradiation, with the lowest value being reached 3 months after the beginning of radiotherapy and increasing gradually during the subsequent months. However, salivary $\mathrm{pH}$ continued to be slightly acid ( $\mathrm{pH}=6.87) 12$ months after treatment, and stimulated salivary flow was reduced by $93 \%$ compared to the beginning of treatment. In the present study, the mean $\mathrm{pH}$ of the two stimulated saliva samples was $6.971 \pm 0.714$. This salivary $\mathrm{pH}$ was also classified as slightly acid. Sixty four percent of the patients presented a salivary flow of less than $0.7 \mathrm{ml} / \mathrm{ml}$, which was in agreement with the study by Möller et al. ${ }^{14}$ (2004) regarding the quantitative and qualitative salivary alterations observed in irradiated patients.

Mucositis generally occurs in the second week of treatment with doses of 2,000 cGy or higher, ${ }^{6}$ and affects about $80 \%$ of irradiated patients. ${ }^{14,20}$ Caielli et al. ${ }^{4}$ (1995) demonstrated that mucositis persisted during treatment and up to two weeks after the end 
of treatment, regressing within a few weeks. Dib et al. ${ }^{6}$ (2000) observed the presence of mild mucositis in the second week of treatment with a dose of up to $1,800 \mathrm{cGy}$, and of severe mucositis in the fifth week of treatment with a dose of 4,500 cGy.

Two cases of mucositis treated with a mean radiation dose of 7,520 cGy ( \pm 3.507; p = 0.044) were observed in the present investigation. One patient was irradiated in the region of the palatine tonsils and epiglottis and the other on the back of the tongue. Both patients were evaluated 2 months after radiotherapy. The low prevalence of mucositis $(2 \%)$ observed in the present study might be explained by the small number of patients who complied with the study during the immediate post-treatment phases.

The most important cause of candidiasis in patients undergoing radiotherapy is xerostomia. The increased number of Candida spp. as a result of radiotherapy may persist for several months after treatment. ${ }^{2}$ We found a significant correlation between the frequency of candidiasis and higher mean postradiotherapy time (39.3 months; $\mathrm{p}=0.028)$. Eleven patients presented chronic candidiasis, and only two of them had concluded radiotherapy less than 9 months before, a fact that could explain the observation of the chronic form.

Candidiasis is a consequence of low salivary flow rates and slightly acid saliva $(\mathrm{pH}=6.971)$, plus the use of old dentures. The large number of edentulous patients using dentures (43\%) in the present sample should be emphasized. Redding et al. ${ }^{17}$ (1999) reported the presence of pseudomembranous candidiasis in $90 \%$ of cases and persisting after the end of radiotherapy. In the present study only the chronic (atrophic) form was found.

The therapeutic measures available for the treatment of head and neck SCC have been questioned in view of the increasing number of patients over the last decades that develop second primary tumors. ${ }^{10}$ Continuous exposure to the same carcinogens (field

\section{References}

1. Barnes L, Eveson JW, Reichart P, Sidransky D. Classification of tumors: pathology \& genetics of head and neck tumors. Geneva: World Health Organization; 2005. cancerization) might be one reason for the increased probability of the occurrence of a second tumor. ${ }^{10}$ Ogata et al. ${ }^{15}$ (1997), retrospectively analyzing 125 patients with head and neck SCC, reported a $10.4 \%$ prevalence of second primary tumor, with the mean time of diagnosis of the second tumor being 36 months. In the present sample, $67 \%$ of the patients were treated for SCC, with the cancer occurring in the mouth in $26 \%$. Two cases of second primary tumor were diagnosed 23 and 72 months after radiotherapy, respectively. These findings emphasize the importance of follow-up with patients treated for SCC of the mouth.

The frequency of osteoradionecrosis depends on the age of the patient, radiation dose, and the irradiated mandibular volume. According to some authors,${ }^{10}$ the period of highest risk ranges from 4 to 12 months postradiotherapy, while others consider the risk to be permanent. ${ }^{11}$ No case of osteoradionecrosis was observed in our study despite the high radiation doses applied and the high proportion of older patients evaluated. The pre-treatment preventive procedures adopted probably contributed to the low risk observed.

\section{Conclusions}

This study suggests that the effects of radiotherapy persist throughout the years and depend on a set of variables which include radiation field, use of xerostomic medication, radiation dose and postradiotherapy time. The main effect of radiotherapy in the head and neck region was a reduction of the salivary flow rate, even though our study demonstrated that there was a modest late improvement of the salivary flow.

\section{Acknowledgments}

We wish to thank the medical team, nurses and staff of the Amaral Carvalho Hospital, Jaú, SP, Brazil, for their direct or indirect participation which permitted the execution of this study.

2. Belazi M, Velegraki A, Koussidou-Eremondi T, Andreadis $\mathrm{D}$, Hin S, Arsenis G et al. Oral Candida isolates in patients undergoing radiotherapy for head and neck cancer: preva- 
lence, azole susceptibility profiles and response to antifungal treatment. Oral Microl Immunol. 2004;19(6):347-51.

3. Boraks S, Chilvarquer I, Panella J. Radiomucosite: contribuição ao estudo dos efeitos das radiações ionizantes na mucosa bucal normal de pacientes portadores de carcinoma espinocelular submetidos a tratamento radioterápico. Rev Odontol UNICID. 2000;12(2):149-61.

4. Caielli C, Martha PM, Dib LL. Seqüelas orais da radioterapia: atuação da odontologia na prevenção do tratamento. Rev Bras Cancerol. 1995;41(4):231-41.

5. Cintra AB, Vale LP, Feher O, Nishimoto IN, Kowalski LP, Angelis EC. Deglutição após quimioterapia simultânea para carcinomas de laringe e hipofaringe. Rev Assoc Med Bras. 2005;51(2):93-9.

6. Dib LL, Gonçalves RCC, Kowalsky LP, Salvajoli JV. Abordagem multidisciplinar das complicações orais da radioterapia. Rev Assoc Paul Cir Dent. 2000;54(5):391-6.

7. Ericsson Y, Hardwick L. Individual diagnosis, prognosis and counseling for caries prevention. Caries Res. 1978;12(Suppl 1):94-102.

8. INCA. Estimativa 2006: incidência de câncer no Brasil; 2006. [acesso 24 ago 2006]. Disponível em: http://portal.saude.sp.gov. br/resources/gestor/destaques/estimativa_incidencia_cancer2006.pdf.

9. Joyston-Bechal S. Management of oral complications following radiotherapy. Dent Update. 1992;19(6):232-4, 236-8.

10. Kufe D, Pollock RE, Weichselbaum RR, Bast RC, Gansler TS, Holland JF et al. Cancer Medicine 6, BC Becker. [book online] [cited 2005 Mar 15]. Available from: http://www.ncbi.nlm.nih. gov/books/bv.fcgi?call=bv.View..ShowTOC\&rid=cmed6. TOCঝdept $H=10$.

11. Lopes MA, Coletta RD, Alves FA, Abbade N, Rossi A. Reconhecendo e controlando os efeitos colaterais da radioterapia. Rev Assoc Paul Cir Dent. 1998;52(3):241-4.

12. Marcucci G. Fundamentos de odontologia: estomatologia. Rio de Janeiro: Guanabara Koogan; 2005.
13. Meraw SJ, Reeve CM. Dental considerations and treatment of the oncology patient receiving radiation therapy. J Am Dent Assoc. 1998;129(7):201-5.

14. Möller P, Perrier M, Ozsahin M, Monnier P. A prospective study of salivary gland function in patients undergoing radiotherapy for squamous cell carcinoma of oropharynx. Oral Surg Oral Med Oral Pathol Oral Radiol Endod. 2004;97(2):17389.

15. Ogata AC, Soares EWS, Soares GVS, Araki LT. Tumor segundo primário em pacientes operados com carcinoma espinocelular de cabeça e pescoço. Rev Bras Otorrinolaringol. 1997;63(6):5836.

16. Pontes CB, Polizello ACM, Spadaro ACC. Clinical and biochemical evaluation of the saliva of patients with xerostomia induced by radiotherapy. Braz Oral Res. 2004;18(1):69-74.

17. Redding SW, Zellars RC, Kirkpatrick WR, Mcatee RK, Caceres MA, Fothergill AW et al. Epidemiology of oropharyngeal Candida colonization and infection in patients receiving radiation for head and neck cancer. J Oral Microbiol. 1999;37(12):3896-900.

18. Silva MA, Damante JH, Stipp AC, Tolentino MM, Carlotto PR, Fleury RN. Gastroesophageal reflux disease: new oral findings. Oral Surg Oral Med Oral Pathol Oral Radiol Endod. 2001;91(3):301-10.

19. Spolidorio DMP, Spolidorio LC, Barbeiro RH, Hofling JF, Bernardo WLC, Pavan S. Avaliação quantitativa de Streptococcus do grupo mutans e Candida sp. e fatores salivares na cavidade bucal de pacientes submetidos à radioterapia. Pesqui Odontol Bras. 2001;15(4):354-8.

20. Vissink A, Jansma J, Spijkervet K1, Burlage FR, Coppes RP. Oral sequelae of head and neck radiotherapy. Crit Rev Oral Biol Med. 2003;14(3):199-212.

21. White SC, Pharoah MJ. Oral radiology: principles and interpretation. $5^{\text {th }}$ ed. St. Louis: Mosby; 2004. 